\title{
David Ricardo's Discovery of Comparative Advantage
}

\author{
Roy J. Ruffin ${ }^{1}$
}

\begin{abstract}
This paper argues that Ricardo's discovery of the law of comparative advantage probably occurred in October 1816. The "Ricardo effect" served as a red herring to cause scholars to possibly misread Ricardo's letters in a crucial period. The letters as well as his book tell a rather beautiful and remarkable story about Ricardo's method of discovery. The modern reconstruction of Ricardo has also led to misunderstandings of his proof. Torrens cannot receive credit for discovery of the law because his statement of comparative advantage is too incomplete for easy scientific reproducibility, and does not even contain the key assumption of international factor immobility.

"There's place and means for every man alive."

William Shakespeare, All's Well That Ends Well

David Ricardo (1772-1823) probably discovered the law of comparative advantage around the first two weeks of October 1816. The date itself is not important, but his letters at the time reveal how Ricardo's mind worked when he discovered the law. If my hypothesis is correct, the letters show his mind ranged over much of the terrain of trade theory—-from factor price equalization conditions to the Ricardian model. I also conjecture that the hard part of his discovery was coming up with the key assumption of factor immobility. The logical nature of his proof is re-examined. Given the importance
\end{abstract}

\footnotetext{
${ }^{1}$ M. D. Anderson Professor of Economics, the University of Houston, Houston, Tx 77204-5019, rruffin@uh.edu. I wish to thank the referees, Bob Clower, Ron Jones, Douglas Irwin, Farhad Rassekh, the late Sherwin Rosen, Joel Sailors, Paul Samuelson, Roger Sherman, and Henry Thompson for comments or discussions on this topic. I am especially indebted to Murray Kemp and Andrea Maneschi. Responsibility for its contents, however, must remain with me.
} 
comparative advantage, how it was discovered may give economists some insight into the process of highly creative thinking.

When asked to name a law of economics that is both true and non-trivial, Paul Samuelson named Ricardo's law of comparative advantage. Historians of the law of comparative advantage have turned a relatively simple and beautiful story into a confused tangle of claims of priority, error, incompleteness, and attribution. It has been said that Robert Torrens (1780-1864) deserves the credit for discovering the law; James Mill (1773-1836) gave the theory to Ricardo; Ricardo had no interest in the law after it appeared; and Ricardo's exposition is deeply incomplete. ${ }^{2}$ Perhaps conflicting claims are to be expected given the importance of comparative advantage. It may be the single best illustration of the power of economic analysis to defeat the forces of foolishness.

Joseph Schumpeter gave four reasons to study the history of economic thought: for direction, inspiration, insight, and economic methodology (Schumpeter, 1954, pp. 45). Learning about how Ricardo discovered the law might fit into all of those categories.

\footnotetext{
2 See Seligman (1911); Chipman (1965); Irwin (1996); and Maneschi (1998) for the Torrens supporters; and J. Hollander (1911), Sraffa (1930), and S. Hollander (1979) for Ricardo's defenders. Viner (1937) is neutral with Ricardo leanings. Thweatt (1976, 1987) and Rothbard (1995) promote James Mill.

Samuelson $(1962 ; 1964)$ has also noted that Torrens should get equal credit, but makes no attempt at historical exegesis. All this is strange because J. Hollander (1911) clearly documents that Torrens recanted whatever claims he may have had and Sraffa (1930) shows Mill had incomplete understanding! Ironically, while disagreeing on some issues, Torrens was one of Ricardo's most dedicated disciples: see Torrens (1844, p. 358): “Adam Smith is, with the single exception of Ricardo, our highest authority on economical questions." See also Ricardo (VII, p. 316) in which there is a quote from a Torrens 1818 letter indicating he was a "convert" to "the doctrines of Ricardo."
} 
Moreover, in view of the importance of attribution in the creation of incentives for the future growth of any science, a historical re-examination of the law of comparative advantage may be useful. As Rosen (1993) has said in a novel defense of the history of economic thought as an academic discipline: “...comparisons with the past help to set and maintain standards of accomplishment in a profession." Thus we need to add Rosen's “professional incentives” to Schumpeter's list.

As a trade theorist, it is with some trepidation that I dispute the conclusions of scholars in the broader area history of economic thought. But without their scholarly and plausible claims, I would not have had the pleasure of examining when Ricardo discovered comparative advantage. Vilfredo Pareto once said: "Give me an error any time, full of seeds, bursting with its own corrections. You can keep your sterile truth for yourself."

Section I of this paper briefly restates the Ricardian law of comparative advantage because it will be convenient to have a compact statement before us in our historical journey. In order to indicate the difficulties in the way of discovering comparative advantage, Section II uses a counterfactual to show that Torrens should not get credit for the law of comparative advantage. Section III then defends my inference that Ricardo discovered comparative advantage around the first two weeks of October 1816 and shows the difference between Ricardo's statement and modern interpretations. Section IV is devoted to Ricardo's other contributions to trade theory. Finally, section V contains some concluding thoughts. 


\section{Ricardo's Law of Comparative Advantage: A Modern Statement}

It is important to begin with a modern statement of Ricardo's law of comparative advantage to fully appreciate Ricardo's own statement and, perhaps, to also understand why some confusion has existed over the nature of his proof. This section fits the definition of a rational reconstruction of Ricardo (Blaug, 1999) because, as we shall see later, Ricardo's own exposition was quite different, leading modern interpreters into unjustified claims of logical incompleteness.

Consider two countries, home and foreign, produce goods 1 and 2. Foreign quantities are designated by asterisk. Each unit of good i requires $a_{i}\left(a_{i}{ }^{*}\right)$ units of labor in the home (foreign) country. Labor can move freely between industries but not between countries. The relative cost of good 1 is cheaper in the home country so that $a_{1} / a_{2}<$

$a_{1} * / a_{2} *$. These "four magic numbers" (Samuelson, 1972, p. 378) determine the pattern of world specialization. Let $\mathrm{p}_{\mathrm{i}}$ be the world price of good $\mathrm{i}$ in some world currency. Since there is a world market, the prices of the goods are the same in each country in the Ricardian world of perfect goods mobility (no tariffs or transport costs). Four principles will then govern our discussion: first, workers earn the value of the goods they produce; second, both goods have to be produced somewhere in the world; third, workers will move into that occupation that pays them the highest income; and fourth, pricing is competitive.

Since $1 / a_{i}$ is the output of one unit of labor, the value of that output is simply $p_{i} / a_{i}$. If a country did not engage in international trade, both goods would have to be produced and workers would allocate themselves so that earnings were the same in both occupations, i.e., $\mathrm{p}_{1} / \mathrm{a}_{1}=\mathrm{p}_{2} / \mathrm{a}_{2}$ or $\mathrm{p}_{1} / \mathrm{p}_{2}=\mathrm{a}_{1} / \mathrm{a}_{2}$. The Smith-Ricardo simple labor theory 
holds in autarky. But when a world market is established, and the prices of the two goods are the same everywhere, it must be that

$$
\mathrm{a}_{1} / \mathrm{a}_{2} \leq \mathrm{p}_{1} / \mathrm{p}_{2} \leq \mathrm{a}_{1} * / \mathrm{a}_{2} *
$$

Why? Suppose (2) were not true. For example, assume that $\mathrm{p}_{1} / \mathrm{p}_{2}<\mathrm{a}_{1} / \mathrm{a}_{2}<\mathrm{a}_{1} * / \mathrm{a}_{2} *$. It would then follow that in both countries $\mathrm{p}_{1} / \mathrm{a}_{1}<\mathrm{p}_{2} / \mathrm{a}_{2}$. and $\mathrm{p}_{1} / \mathrm{a}_{1} *<\mathrm{p}_{2} / \mathrm{a}_{2} *$. Thus, in both countries, workers would flock to industry 2 . As long as good 1 is demanded, the price of good 1 would have to rise relative to good 2 until inequality (2) is established.

When (2) holds, it will be the case that it always pays the home country to produce good 1 and the foreign country to produce good 2 because workers move to the high-paying industry. If the price ratio is strictly in between the two labor-cost ratios, both countries will be completely specialized.

If $\mathrm{w}$ and $\mathrm{w}^{*}$ are wage rates in world currency, the Ricardian pattern of specialization requires that the world prices be: $\mathrm{p}_{1}=\mathrm{wa}_{1}$ and $\mathrm{p}_{2}=\mathrm{w}^{*} \mathrm{a}_{2} *$. This immediately implies that the ratio of prices - relative values-- is affected by relative wage rates between two types of labor, home and foreign. It is a minor puzzle that Ricardo did not apply this result in Chapter 1 of his Principles of Political Economy and Taxation $\left(1^{\text {st }}\right.$ Ed., 1817; $3^{\text {rd }}$ Ed., 1821 ) in which he dealt with the question of different types of labor. In this case the two labor types are home and foreign instead of different types of domestic labor.

Since commodity prices are determined in the low cost country, inequality (2) may also be written as:

$$
\mathrm{a}_{2} * / \mathrm{a}_{2} \leq \mathrm{w} / \mathrm{w}^{*} \leq \mathrm{a}_{1} * / \mathrm{a}_{1},
$$


which shows the home country's wage disadvantage (w/w*) must fall short of its highest productivity advantage $\left(a_{1} * / a_{1}\right)$, but be higher than its lowest productivity advantage $\left(a_{2} * / a_{2}\right)$. Thus, factor prices between countries are a fundamental part of the law of comparative advantage, and are also a clue to our story.

The inequalities in (2) or (3) may be called the Ricardian law of comparative advantage. ${ }^{3}$ It may also be useful to point out that the law has a separation property: we can deduce any one country's pattern of specialization just from the price ratio and the relative cost ratio, no matter how many countries. Ricardo took great advantage of this separation property and used it to prove his theorem. Indeed, one of his rules was that "every transaction in commerce is an independent transaction" (Ricardo, I, p. 138). ${ }^{4}$ John Elliot Cairnes (1823-1875) beautifully summarized the essential nature of comparative advantage and the necessity of examining the "four magic numbers."

According to Cairnes (1874, p. 312):

"when it is said that international trade depends on the difference in the comparative, not the absolute, cost of producing commodities, the costs compared, it must be carefully noted, are the costs in each country of the commodities which are the subject of exchange, not the different costs of the same commodity in the exchanging countries....England might be able to raise coal at onehalf the amount of labour and abstinence needed in France; but this alone would not render it profitable for France to obtain her coal from England." (Cairnes, 1874, p. 312).

Thus, the "Cairnes' rule" is that we compare $a_{1} / a_{2}$ with $a_{1} * / a_{2} *$ and not $a_{i}$ with $a_{i} *$.

\footnotetext{
${ }^{3}$ There are other definitions of the term "comparative advantage" (for instance, anything that causes a difference between countries) but for this paper I always mean the Ricardian law.
} 


\section{The Role of Torrens}

The main purpose of this paper is to show how and when Ricardo discovered the law comparative advantage. I discuss Torrens only to indicate the difficulties faced by anyone trying to discover the law.

In this section I show that while Torrens had the insight that absolute advantage may not decide whether a good would be imported, he did not bequeath tools that would have enabled one to easily prove the law of comparative advantage. There is difference between hinting a result and providing the tools to prove a theorem. Shakespeare (see quote at the beginning of paper) may have grasped its "essence" when applied to individuals, but he could hardly be given credit for the theorem.

It was Edwin Seligman who alerted the profession to Torrens (Seligman, 1903). ${ }^{5}$ A vigorous debate ensued between Seligman (1911) and Jacob Hollander (1911), who pointed out that (1) Ricardo's theory requires international immobility of factors; (2) the statement of comparative advantage must include or imply Cairnes' rule; and (3) in any case Torrens recanted his claim in 1844. Then John Chipman's masterful survey of international trade theory asserted "that credit for the principal discovery should go to Torrens (Chipman, 1965, p. 482)." The debate subsided for another thirty years until Douglas Irwin and Andrea Maneschi repeated the Chipman claim, and so, it has cascaded down the corridors of academia (Irwin, 1996; Maneschi, 1998).

One of the reasons Chipman credits Torrens is that there is nothing in Ricardo's 1815 Essay on Profits (Ricardo, IV) that touches on comparative advantage. But Torrens' External Corn Trade (1815), which was published on the same date, contains an

\footnotetext{
${ }^{4}$ I will refer to Ricardo's Works and Correspondence by indicating the volume number.

${ }^{5}$ John Stuart Mill (1848, Book III, Chapter 17) was probably the original source for this claim.
} 
important paragraph emphasized by Seligman (1903) describing, according to Chipman, "the essence of the law of comparative advantage (Chipman, 1965, p. 481)." My disagreements do not in the least detract from the services performed by Chipman and others; for they were covering many subjects, and as we all know the broader the net the more likely one is going to catch a few old boots. But still there is room for "the old man in the sea" to catch his prize fish!

The basis for giving priority to Torrens is his 1815 statement that a country might import something in which the country has an absolute advantage. The statement earns a gold star, perhaps, but I will argue that it does not merit scientific sainthood. It is instructive to look at the entire quote:

"Let us suppose, that there are, in England, unreclaimed districts, from which corn might be raised at as small an expense of labour and capital, as from the fertile plains of Poland. This being the case, and all other things the same, the person who should cultivate our unreclaimed districts, could afford to sell his produce at as cheap a rate as the cultivator of Poland; and it seems natural to conclude, that if industry were left to takes most profitable direction, capital would be employed in raising corn at home, rather than bring it in from Poland at an equal prime cost, and at a much greater expense of carriage. But this conclusion, however obvious and natural it may, at first sight, appear, might [italics added], on closer examination, be found entirely erroneous. If England should have acquired such a degree of skill in manufactures, that, with any given portion of her capital, she should prepare a quantity of cloth, for which the Polish cultivator would give a greater quantity of corn, than she could, with the same portion of capital, raise from her own soil, then, tracts of her territory, though they should equal, nay, even though they should be superior, to the lands in Poland, will be neglected; and a part of her supply of corn will be imported from that country.[italics added]... Though the capital employed in cultivating at home might bring an excess of profit over the capital employed in cultivating abroad, yet, under the supposition [italics added], the capital which should be employed in manufacturing would obtain a still greater excess of 
profit; and this greater excess of profit would determine the direction of our industry (Torrens, 1815, pp. 263-65)."

In the1826 edition of his Essay on the Corn Trade Torrens claimed that the above statement showed "for the first time, that . . commodities, the cost of producing which is greater in foreign countries than at home, may, nevertheless, be imported...." ${ }^{6}$ However, the above statement may be correct only because we know Ricardo's theory of comparative advantage. Two questions need to be asked: What is wrong with the statement? What can be done with the statement?

What is wrong? First, Torrens did not make a careful accounting of the factor costs of production in both countries of all the goods "subject to exchange," as required by inequality (2) above. For example, the statement alludes to the fact that England should produce manufacturers even if it superior to Poland in corn production. But suppose Poland's productivity disadvantage was smaller in manufacturing than in corn production! Then the statement would even be wrong. ${ }^{7}$ Lionel Robbins pointed out that "as pure analysis it still lacks the final emphasis upon the comparison of ratios which is the ultimate essence of the principle" (Robbins, 1958, p. 23). Second, the statement said nothing about the key assumption of trade theory--the inability of factors to move from a country where productivity is low to another where productivity is higher. Torrens did not mention either one of these requirements for the theory of comparative advantage. These observations are Ricardo's "home runs." Ricardo emphasized the "four magic

\footnotetext{
${ }^{6}$ It is interesting to note that there is no record in Ricardo's correspondence that Torrens publicly or privately made this claim during Ricardo's lifetime.

${ }^{7}$ I am indebted to Murray Kemp for this observation.
} 
numbers" as well as stating that because Portugal has an absolute advantage in the production of both cloth and wine:

\begin{abstract}
"it would undoubtedly be advantageous to the capitalists of England, and to the consumers of both countries, that under such circumstances, the wine and the cloth should both be made in Portugal, and therefore that the capital and labour of England employed in making cloth, should be removed to Portugal for that purpose.”(Ricardo, I, p. 136)
\end{abstract}

Accordingly, Ricardo realized it was necessary to suppose factor immobility between countries. Indeed, of the 973 words Ricardo devoted to explaining the law of comparative advantage, 485 emphasized the importance of factor immobility! ${ }^{8}$

What can be done with the statement? In Torrens' incomplete discussion, land, labor, capital, and transportation costs are mentioned. The third sentence in the quote from Torrens even throws in that little word, "might," to suggest some uncertainty. The italicized portion of the quote can be made correct if we read into it the Ricardian assumptions, but that is reading too much into it. ${ }^{9}$ A counterfactual will show the problem of reconstructing comparative advantage. Consider the pioneering work of Murray Kemp and Ronald Jones (Kemp, 1966; Jones, 1967) in which there are two countries producing two goods with the aid of capital and labor under constant returns to scale, but production functions differ across countries and only capital is mobile across national boundaries. The Kemp-Jones model is exceedingly difficult. Jones was able to somewhat simplify the model (Jones, 1967) by employing the classic Samuelson duality properties of the Heckscher-Ohlin model (Samuelson, 1953), but the model can still

\footnotetext{
${ }^{8}$ My word processor count includes the ten paragraphs starting with "The same rule which..." (I, p. 133) and ending with "more advantageous employment for their wealth in foreign nations. (I, p. 137)."

${ }^{9}$ I am indebted to Andrea Maneschi for this point.
} 
exhibit many patterns of specialization (Chipman, 1971; Jones and Ruffin; 1975; Ruffin, 1984). Therefore, without the simplifying assumptions that Ricardo bequeathed to us, developing the theory of comparative advantage would have faced great difficulties. Thus, it was not known until the work of Kemp and Jones that the basic insight of Ricardo is completely preserved even in a model with perfect capital mobility. In other words, partial factor mobility does not change the basic truth of the law of comparative advantage. Every country has a place at the table of world markets, no matter how high the country's competitively determined wages or how poor its circumstances of production (provided only that the level of real income is one on which people can survive). To bring home this point, in a once influential paper, Williams (1929) asserted that the international movement of some of the productive factors might vitiate the basic conclusions of the theory. One still hears echoes of this criticism today (Lang and Hines, 1993, p. 22).

Thus, Torrens cannot be given credit for the law of comparative advantage simply because scientific advancement requires practical reproducibility in both experiments and theorems. He did not even hint that factors of production must be internationally immobile in order for comparative advantage to reign supreme. Moreover, Jacob Hollander (1911, p. 460) provided extensive quotations from The Budget (1844) that conclusively show that Torrens indirectly recanted his claims of priority by emphatically and repeatedly attributing comparative advantage to Ricardo's “celebrated chapter upon Foreign Trade." ${ }^{\prime 10}$ Indeed, he himself began to stress the importance of Ricardo's

\footnotetext{
${ }^{10}$ See Torrens, 1844, pp. v, vi, viii-ix, and "Letter X", pp. 336, 342-345, 405. None of the "antiRicardians" of today have mentioned his recantatation.
} 
assumption that factors are immobile between countries (Torrens, 1844, pp. viii-ix).

Under these circumstances, it is too generous and misleading to refer to the "RicardoTorrens theory of comparative advantage (Maneschi, 1998)." 11

\section{Ricardo's Discovery of the Law of Comparative Advantage}

How and when did Ricardo discover comparative advantage? It is actually very easy to show that he discovered the law sometime between March and October of 1816, explaining Chipman's perplexity that Ricardo did not mention comparative advantage in his 1815 Essay on Profits (Chipman, 1965). In October 1816, Ricardo sent the first seven chapters of his Principles to James Mill. On November $18^{\text {th }}$, 1816 James Mill wrote Ricardo: "that it may be good for a country to import commodities from a country where the production of those commodities costs more, than it would cost at home: that a change in manufacturing skill in one country, produces a new distribution of the precious metals, are new propositions of the highest importance, and which you fully prove (Ricardo, VII, p. 99)." Mill's crediting the discovery of comparative advantage to Ricardo establishes the October date. Any claims that James Mill actually gave the law

\footnotetext{
${ }^{11}$ It might be noted that Torrens vigorously opposed England's unilateral adoption of free trade in the 1840s (Robbins, 1958, p. 206). Some have interpreted this opposition favorably in terms of the optimal tariff argument (Irwin, 1996). But the optimal tariff argument is for an incipient revenue tariff against which there is no retaliation; it is not a terms of trade argument. If a large country cut 99 percent of its exports, its terms of trade would improve but it would be worse off. Torrens $(1844$, p. 336) seriously erred in asserting that if two countries had imposed the same 100 percent tariff rates "it would not necessarily follow that the aggre gate wealth or the aggregate consumption of either country would diminish by this contraction of its foreign trade.” Imagine Ricardo making that mistake!
} 
of comparative advantage to Ricardo, as argued by Thweatt (1976), must explain this letter. $^{12}$

What about the March date 1816 date? He did understand as early as 1811 "that it is the relative value of commodities which regulates their exportation (Ricardo, VI, p. 64)." A good beginning, but the statement is not the same as the Ricardian law of comparative advantage, because it requires a theoretical basis. Also, by 1811 Ricardo had worked out in his own mind how exchange rates, commodity prices, transportation costs, and the distribution of the precious metals fit together (Ricardo, VI, pp. 72-76). It is also possible to discuss these factors without any discussion of productivity. Fortunately, Samuel Hollander (1979, p. 185) pointed the way when he shrewdly observed that Ricardo did not have a strict labor theory of value in 1815. This explains Sraffa's puzzlement that “it is remarkable that in ... [Ricardo's] letters of October and November of 1815 which give the main headings of the proposed work (Rent, Profit, Wages) there is no reference to value (Ricardo, I, p. xiv)." Indeed, Ricardo had not adopted the labor theory of value up to his February $7^{\text {th }}, 1816$ letter to Malthus in which he discloses, "If I could overcome the obstacles in the way of giving a clear insight into the origin and law of relative or exchangeable value I should have gained half the battle

\footnotetext{
${ }^{12}$ Moreover, it has been pointed out by Sraffa (1930) that James Mill did not fully comprehend the gains from international trade because of an error in his exposition that he attempted to remove (without success in my opinion) in the 1826 edition of his Elements of Political Economy. Thweatt (1987) tries to justify the error by arguing that it was actually made by his teenage son, John. John did attempt to defend his father's apparent mistake, but also fell into a misinterpretation of Ricardo's presentation (see below). I point out later that Ricardo also stated the celebrated "Lerner symmetry theorem," which is certainly consistent with having a complete understanding of the nature of international trade.
} 
(Ricardo, VII, p. 20).” Thus, without the labor theory, we are clearly into 1816 before Ricardo developed comparative advantage.

Ricardo adopted the labor theory of value around March 1816. How do we know this? Malthus was visiting Ricardo for a few days around March $9^{\text {th }}, 1816$. The next time we have a letter from Malthus is April $28^{\text {th }}, 1816$, in which he said: "On the subject of determining all prices by labour, ..., I think you must have swerved a little from the right course (Ricardo, VII, p. 30).” Clearly, during Malthus' visit, Ricardo must have informed him of his newly adopted labor theory.

For the next several months Ricardo did little if any work on the book. On the May $28^{\text {th }}$, 1816, Ricardo told Malthus: "My labours have wholly (italics added) ceased for two months (Ricardo, VII, p. 36)." Thus, it is highly reasonable to put his discovery between June and October of 1816.

What is the evidence that Ricardo discovered comparative advantage in late September or the first few weeks of October 1816? The reason that other scholars failed to note the importance of the October letters is that they were thrown off the track by a "red herring," the proposition that an increase in wages can lower the relative value of capital-intensive goods (Schumpeter, 1954, p. 595). Indeed, this "Ricardo effect" is discussed several times early in Ricardo's Principles in his various "modifications" of the principle that prices reflect labor costs (see Stigler, 1958). Obviously, the Ricardo effect is a crude version of matters that are now included in the famous Stolper-Samuelson theorem.

There are three critical letters. The first was to Malthus October 5, 1816, in which Ricardo first indicates he is "impeded" by a problem. The second was to Malthus, 
October 11, 1816, in which he admits extreme forgetfulness and describes a factor price equalization world that is similar to some phrasing in Chapter 7. The last was to Mill, October 14, 1816, in which he indicates he has solved a problem in value theory that deeply puzzled him and would now turn to taxation. The middle letter I shall discuss last.

In the October $5^{\text {th }}$ Malthus letter Ricardo expressed the fear that he had little hope that he could submit his views to the public because, he continued:

"I have been very much impeded by the question of price and value, my former ideas on those points not being correct. My present view may be equally faulty, for it leads to conclusions at variance with all my preconceived opinions (Ricardo, VII, pp. 71-72).”

The editor (Sraffa) then placed this footnote: "His 'present view' very probably refers to 'the compatibility of a rise of wages with a fall of prices'(Ricardo, VII, p. 72n)."

In the remarkable Mill October $14^{\text {th }}$ letter Ricardo almost tells us he has just figured out comparative advantage. He begins the letter talking about the bad state of his papers and apologizes for exposing them "even to your friendly eye. (Ricardo, VII, p. 82)." He then refers to the Ricardo effect:
"You will see the curious effect which the rise of wages produces on the prices of those commodities which are chiefly obtained by the aid of machinery and fixed capital. I hope ...you will give me your well considered opinion on this difficult point. There are tables in which calculations are given of the present value of an annuity for any number of years to come..."

His next paragraph rejected a suggestion by Mill to hire someone to copy the material, because he was constantly making corrections. It is the next paragraph that contains what I think is the most important point when one realizes that it is comparative advantage that Ricardo is talking about.

"I have been beyond measure puzzled to find out the law of price. I found on a reference to figures that my former opinion could not be correct and I was full a fortnight pondering on my difficulty 
before I knew how to solve it. During that time I could not proceed or I should have made greater progress. I shall now consider the subject of taxation (Ricardo, VII, p. 84).”

I infer that Ricardo had foreign trade in mind, not the Ricardo effect that Sraffa guessed. Why? First, the Ricardo effect is just a "curious effect" and not one that is "puzzling." Second, the discussion of being "puzzled" did not immediately follow his mention of the tables illustrating the Ricardo effect. Under Sraffa's hypothesis it would seem Ricardo would have said, "I just spent two weeks working on this curious effect." Third, the "curious effect" does not affect the law of price, interpreted as meaning prices conform to the cost of production, especially in view of George Stigler's interpretation of Ricardo's "93" percent labor theory (Stigler, 1958). But the law of comparative advantage is a different matter: to Ricardo it must have appeared to strike at the heart of his labor theory of value. Most significantly, Ricardo begins his discussion of comparative advantage with the famous statement: "The same rule which regulates the relative value of commodities in one country, does not regulate the relative value of the commodities exchanged between two or more countries (Ricardo, I, p. 133)." In domestic trade, two goods trade for each other according to labor costs; but in international trade, the goods that trade can contain quite different quantities of labor. Does it not seem clear that this phenomenon may well be the "law of price" to which Ricardo was referring in his letter? His "former opinion" may well have been that value was always governed by relative labor costs. ${ }^{13}$ Fourth, the last sentence in the above quote, "I shall now consider the subject of taxation," which is Chapter 8 following "On Foreign Trade." If Ricardo wrote the Principles in sequence, as is likely, he would have been working on comparative advantage. 
The middle letter to Malthus on October $11^{\text {th }}$ supports the interpretation that Ricardo was working out comparative advantage. If my hypothesis is correct, it is in some ways the most amazing letter of all because it shows Ricardo was thinking about factor price equalization at this time. At the end of the letter he said to Malthus:

"What would you say of two countries in which there are precisely equal capitals --where wages are also equal, and where the populations are precisely the same number? Would the demand compared with the supply of capital be the same in both? If you say they would I ask whether their rate of profits would be the same under any other supposition but that their land being exactly the same degree of fertility? (Ricardo, VII, p. 79)"

This is fortuitous for my hypothesis because Chapter 7 (Ricardo, I, p. 142) also discusses factor price equalization conditions in a similar way. Moreover, this is relevant because factor prices between countries are deeply involved in comparative advantage. Thus, it may indicate that Ricardo may have used extreme cases to illuminate or clarify his thinking. ${ }^{14}$ In other words, in order to figure out comparative advantage, he may have considered the disparate consequences of completely opposite views of the world, one where the countries are identical with several factors and one where they had different technologies and only one factor. If my hypothesis is correct, during this two-week period his mind ranged over much of the terrain of international trade theory!

It is reasonable to assume that enormous concentration was required to discover the law of comparative advantage because of its counter-intuitive nature. The Malthus October $11^{\text {th }}$ letter contains corroborating evidence of the mental effort he told us about in his letter to Mill on October $14^{\text {th }}$ in which he was "beyond measure puzzled." These

\footnotetext{
${ }^{13}$ As a possible consequence, perhaps, Ricardo never used the phrase, "the law of price," in his Principles.
} ${ }^{14}$ It should be pointed out that Malthus pushed Ricardo into this corner as early as May 1815 (Ricardo, VI, pp. 223-229). 
are strong words. It took him a full two weeks to ponder the "difficulty." Ricardo's "world view" was dominated by the pleasures he found in thinking about the corn-laborbullion nexus (see Ricardo, VI, p. 241). As I indicated above, foreign trade confronted Ricardo with something that looked to him quite different. But we do not have to guess that he was completely absorbed by the problem--he told us! Ricardo apologized to Malthus over an overlooked invitation, "I forgot the day of the week and was not aware, till I got home that we were so near Saturday (Ricardo, VII, p. 78)." His letters always showed great concern over the days of the week, as would have been required by his stellar business career. It interesting to note that at no other time in the 14 years covered by his published letters did Ricardo complain that he "forgot the day of the week."

Apparently, after solving his problem he then immediately bundled the first seven chapters of his book and sent them to Mill. This fact is significant because it means the problem he was working on almost surely was comparative advantage. The most reasonable assumption is that when he wrote Chapter 1 he had not worked out the law of comparative advantage because of his statement about relative prices and relative wages. He certainly was aware in Chapter 7 that his theory applied to this case as well; for we have the tremendous footnote in which he applied the theory:

\footnotetext{
"Two men can both make shoes and hats, and one is superior to the other in both employments; but in making hats he can only exceed his competitor by one-fifth or 20 per cent; and in making shows he can excel him by one-third or 33 per cent: will it not be in the interest of both that the superior man should employ himself exclusively in making shoes, and the inferior man in making hats (Ricardo, I, p. 136).”
}

Ricardo did not significantly change Chapter 1 in subsequent editions because he doubted his writing skills. For example, in his $23^{\text {rd }}$ November, 1818 letter to Mill he said: "I am 
afraid to make many alterations in it... with such an unskillful hand... (Ricardo, VII, p. 333)."

If Sraffa's plausible conjecture is true, then Ricardo was deeply troubled about a "curious effect" that is simply based on a compositional question that should have been pretty obvious to one with such quantitative gifts. The Ricardo effect arises from the fact that the fraction of labor costs differs among goods; thus, when wages rise the relative value of goods that are capital-intensive should fall. I would think that this elementary calculation would have been obvious to a Ricardo. Moreover, it was his deeply held belief that the "greater or less durability of capital...never superceded" but only "modified" the principle that exchange values conform to labor costs (Ricardo, VII, p. $377) .^{15}$

Ricardo's discussion of comparative advantage is preceded by a general discussion of the links between trade and welfare:

"Foreign trade, then, though highly beneficial to a country, as it increases the amount and variety of the objects on which revenue may be expended, and affords, by the abundance and cheapness of commodities, incentives to saving, and to the accumulation of capital, has no tendency to raise the

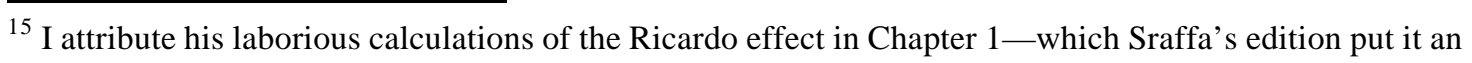
Appendix---to the fact that he enjoyed numbers. For example, Ricardo remarked, "I have been amusing myself for one or two evenings in calculating" elaborate tables of exchange rates and gold prices (Ricardo, VI, pp. 97-101). This is evident throughout his letters (e.g., Ricardo, VIII, p. 85). The time element is also important. If Ricardo was writing Chapter 1 during this two-week period, he then would have had to write the chapter on Foreign Trade earlier and there is no evidence of the intense intellectual effort required to invent comparative advantage in earlier letters. Thus, the odds are not in favor of Sraffa's conjecture, though it has enough plausibility to prevent conviction in a court of law!
} 
profits of stock, unless the commodities imported be of that description on which the wages of labour are expended (Ricardo, I, p. 133).”

The first part of the above statement, that trade increases "the amount and variety" of the mass of commodities, is an illusion to the static effects of trade. The second part of the statement suggests trade is related to economic growth, though not necessarily to profits unless imports cheapen the goods purchased by workers and, thus, lower wages and raise profit, as in the familiar Ricardian refrain about income distribution. After a paragraph describing Ricardo's general views on profits, he then makes his famous statement that "The same rule which regulates the relative value of commodities in one country, does not regulate the relative value of the commodities exchanged between two or more countries."

Now Ricardo wanted to show the "principle which determines that wine shall be made in France and Portugal, that corn shall be grown in America and Poland, and that hardware and other goods shall be manufactured in England." The structure of his widely misunderstood proof is as follows. Following a discussion of the international immobility of productive factors, Ricardo states what amounts to a theorem. "The quantity of wine which she [Portugal] shall give in exchange for the cloth of England, is not determined by the respective quantities of labor devoted to the production of each, as it would be, if both commodities were manufactured in England, or both in Portugal. (Ricardo, I, pp. 134-135)." Ricardo then goes on to prove this theorem. I restate his logic. Let X be "the quantity of wine" that is traded for Y units of cloth. If England requires 120 men for one year to make $\mathrm{X}$ units of wine and 100 men to make $\mathrm{Y}$ units of cloth, "England would therefore find it her interest to import wine, and to purchase it by 
the exportation of cloth."16 He then went on to Portugal, which required 80 men to produce the wine and 90 to produce the cloth. Obviously, Portugal would save 10 men producing $\mathrm{X}$ wine and trading it for England's Y cloth. ${ }^{17}$

"Thus England would give the produce of the labour of 100 men for the produce of the labour of 80. Such an exchange could not take place between the individuals of the same country. The labour of 100 Englishmen cannot be given for that of 80 Englishmen, but the produce of the labour of 100 Englishmen may be given for the produce of the labour of 80 Portuguese, 60 Russians, or 120 East Indians.”

The above quote provides the key to what Ricardo meant by his famous statement that domestic trade and international trade obey different rules: he obviously meant just what he said above. That statement may be taken to mean the hard part of comparative advantage because it says poor countries can trade with rich countries and both can still gain.

Ricardo's proof is elegant, simple, and sublime. It not only uses the separation property of the law of comparative advantage, but the logical structure applies to any

\footnotetext{
${ }^{16}$ Chipman (1965, p. 479) misinterpreted Ricardo's proof when he said, “This is a non sequitur, since nothing so far has been said about Portugal" by overlooking the fact that Ricardo was in effect starting with the terms of trade. This remark has, unfortunately, been approvingly quoted by Thweatt (1976, p. 221) and Maneschi (1998, p. 53), but is probably explained by the tendency to read Ricardo in the light of the rational reconstruction of Ricardo in modern presentations. Maneschi (2000) now agrees with the interpretation presented in an earlier version of the present paper.

${ }^{17}$ John Stuart Mill misinterpreted Ricardo’s presentation when he said, "Mr. Ricardo...unguardedly expressed himself as if each of the two countries gained the whole of the difference between the comparative costs of the two commodities in the one country and in the other (Mill, 1844, p. 10).” On my interpretation, Ricardo was correctly relating the terms of trade to the comparative costs in each country. Sraffa reaches the same conclusion (Sraffa, 1930, p. 541).
} 
number of goods or countries, unlike textbook expositions. ${ }^{18}$ Had Ricardo worked from factor endowments and preferences to comparative advantage, the discovery would have been made more difficult. It was John Stuart Mill who gave the analysis of comparative advantage the form that became an engine of analysis for generations to come and the starting point for all further developments in trade theory. ${ }^{19}$ Thus, John Mill was responsible for the rational reconstruction of Ricardo in which the labor cost coefficients were interpreted as the amounts used in a unit of each good produced rather than Ricardo's labor cost of producing the amounts contained in a typical trading bundle. Ricardo was exceedingly lucky. Malthus was always pursuing him with hard questions and early on Ricardo had the correct notion that it was relative prices that determined trade patterns. He later embraced the view that labor costs determined "93 percent" (Stigler, 1958) of relative values. It was thus natural for him to think in terms of a simple labor cost model. When he turned to foreign trade, after Malthus had forced him to think in terms of two identical countries, he could see that in the real world a certain amount of labor in one country did not trade for the same amount of labor in another country. It was then relatively easy to construct the law of comparative advantage

\footnotetext{
${ }^{18}$ Viner (1937, p. 444) confuses the logical structure of Ricardo's exposition with textbook accounts. Any number of goods or countries can be used. For example, if cloth, corn, and wine trade on the world market at the ratios $\mathrm{X}: \mathrm{Y}: \mathrm{Z}$, then any single country, among possibly many countries, will devote its resources to the good requiring the least amount of labour to produce $\mathrm{X}$ cloth, Ycorn or $\mathrm{Z}$ wine. It immediately follows that absolute advantage or disadvantage does not matter if labour cannot move across borders. Seen in this light, Ricardo makes the theorem obvious---a common feature, I believe, of many intellectual discoveries. ${ }^{19}$ See Chipman (1965, pp. 483-91) for an exposition of Mill's formulation that more than makes up for his occasional lapses on the historical front. See also Ruffin (1988) for another exposition.
} 
because he only had to work with internationally mobile goods and internationally immobile labor. His struggle may very well have been coming up with the key assumption that labor cannot move from England to Portugal. As we indicated earlier, in Chapter 7 he devoted as much space to factor immobility as explaining or proving the law of comparative advantage proper-a proof that is actually introduced by a 192 word treatment of factor immobility and capped by another 293 word analysis of factor immobility. Ricardo's penchant for abstraction and logical arguments then, after two weeks of intense thought, led him to the beautiful law of comparative advantage, which just happens to hold under much broader circumstances.

\section{Ricardo's Other Discussions of Trade Theory}

Evidently, it was Ricardo who first coined the term "comparative advantage (See also Maneschi, 1998, p. 55)." For example, in Chapter 19 he said, "a new tax too may destroy the comparative advantage which a country before possessed in the manufacture of a particular commodity" (Ricardo, I, p. 263). To Malthus on June $24^{\text {th }}, 1818$, he discussed "the comparative advantage of employing capital in agriculture or on manufactures" and that "wealth...would be most effectually increased by allowing corn to be grown, or imported, as best suits those concerned in the trade (Ricardo, VII, p. 270271)."

Ricardo was the first to dispute Adam Smith's "vent for surplus" theory that foreign trade carried off the surplus production of goods beyond what is required at home. J. S. Mill (1848, Book 3, Ch. 17) named the theory and in the unusual history of international trade has thereby been given credit for first rejecting the theory. Ricardo remarked in a footnote: 
"One would be led to think by the above passage that Adam Smith concluded that we were under some necessity of producing a surplus of corn, woolen goods, and hardware, and that the capital which produced them could not be otherwise employed. It is, however, always a matter of choice in what way a capital shall be employed (Ricardo, I, p. 291 note)."

Ricardo then goes on to recapitulate the theory of competitive resource allocation, which is at the heart of comparative advantage.

Finally, in 1822 he wrote Protection to Agriculture (Ricardo, IV). In this essay he summarized his views on a wide range of topics, but most clearly expressed why he believed in free trade. He then explained how in a world in which we protected every good, through either export subsides (called drawbacks in those days) or import duties, we would end up protecting no one. Hence, he pointed out an equivalent form of what we now call "Lerner's symmetry theorem (Lerner, 1936)." It is clear in this essay that Ricardo viewed the economy as a vector of equilibrium prices, and that only relative prices mattered. Ricardo's statement of the theorem:

\footnotetext{
"If England gave a yard of.. .cloth to Germany for a quarter of wheat, she would neither be more nor less disposed to carry on this trade, if both cloth and corn were raised 20 per cent. in price. All foreign trade finally resolves itself into an interchange of commodities. It is essential that a drawback should be allowed on the exported article, if the one imported be protected by a duty. But it comes to the same thing, if no drawback be allowed on the one, nor protection granted to the other, because, in either case, precisely the same quantity of the foreign commodity will be obtained for a given quantity of the home-made commodity (Ricardo, IV, p. 214).”
} 
Ricardo had an uncanny knack for addressing himself to the big questions. ${ }^{20}$ Thus, he addressed himself to the symmetry of import and export duties - the foundations of tariff theory-- instead of the smaller question of the terms of trade effects of tariffs (addressed by Torrens). ${ }^{21}$ Indeed, the Ricardo-Lerner theorem is the principle on which European countries impose their value-added taxes on imports while rebating them on exports. ${ }^{22}$

\section{Concluding Thoughts}

In an important letter to McCulloch on March 23, 1821, Ricardo discussed his arguments for free trade, stated how export bounties can offset import duties, and referred to his law of comparative advantage. The letter shows Ricardo's remarkable quantitative insight that protection to agriculture could keep profits at home higher than abroad:

"I have put the case in my book [I, p. 136, note] of a country having a very little superiority over its neighbours in the production of corn but a very great one in the production of manufactured goods. In such a country, notwithstanding a corn law, profits would be higher than in the neighbouring countries, and consequently no capital would flow from it (Ricardo, VIII, p. 358).”

\footnotetext{
${ }^{20}$ Another example: Sayers (1953) points out that it was Ricardo who suggested that the gold standard depended more on convertibility than on the use of gold coins. The Barro-Ricardo equivalence theorem is another example (Buchanan, 1976).

${ }^{21}$ Kemp (1956, p. 114) traces the symmetry of import and export taxes back to Alfred Marshall and to “hints" in J.S. Mill. Ricardo's sensed symmetry in a March $9^{\text {th }}, 1815$ letter to Malthus in which he said "a tax on exportable commodities in a country which imports corn does not act very differently from a duty on the importation of corn (Ricardo, VI, p. 181)."

22 Torrens also claimed to have discovered this principle as well (Hollander, 1992, p. 652).
} 
This shows that Ricardo never gave up on comparative advantage ${ }^{23}$ but it also shows his ability to see the world in more general terms than his simple labor cost view. If two countries have the same commodity prices and the same profit rate, under the conditions postulated by Ricardo the advanced country would be specialized in manufacturers and the undeveloped country in corn. If a tariff is imposed on corn, then the rate of profit could be higher in the more advanced country.

Alfred Marshall had unbounded praise for Ricardo: "The genius which enabled Ricardo...to tread his way safely through the most slippery paths of mathematical reasoning, though he had no aid from mathematical training, had made him one of my heroes (Keynes, 1924b).” John Maynard Keynes expressed the opinion (around 1922) in the presence of biographer and friend Roy Harrod that "Ricardo was the greatest [most distinguished] mind that found economics worthy of its powers" (Harrod, 1951, p. 467 and p. 328; Harrod, 1946, p. 182; and Samuelson, 1962, p. 9). Keynes probably had in mind Ricardo's work on monetary questions, ${ }^{24}$ but a good case can be made that the basis for this statement would seem to be the incredible array of basic contributions over Ricardo's short period of work into economics.

\footnotetext{
${ }^{23}$ Thweatt (1976, p. 221) and Rothbard (1995, pp. 97-98) claim otherwise. According to Rothbard, "The three paragraphs on comparative advantage...were the only account...that Ricardo would ever write on comparative advantage. Indeed, this was his only mention at any time of this doctrine." Rothbard is also contradicted by Ricardo's Principles when in his Chapter 25 he said: "Foreign trade, ..., will always continue, whatever may be the comparative difficulty of production in different countries" (Ricardo, I, p. 343). This statement is a clear deduction from the law of comparative advantage.
} 
Ricardo's discovery of the law of comparative advantage must rank as one of the more remarkable stories in the history of economic thought. Luck, genius, a desire to contribute to political economy, and two weeks of intense thought united in a super rich stock jobber to give economics one of its most fundamental laws. No law is more subtle yet more obvious on deep reflection; that is what made it so difficult to discover.

24 “Ricardo's greatest works were written as ephemeral pamphlets" (Keynes, 1924a, p. 344). See also Sayers (1953, p. 49) for Ricardo's contribution to the institutional set-up of the Bank of England. 


\section{References}

Blaug, Mark (1999). "Misunderstanding Classical Economics: The Sraffian Interpretation of the Surplus Approach," History of Political Economy, Vol. 31, pp. 214-236.

Buchanan, James M (1976)."Barro on the Ricardian Equivalence Theorem " Journal of Political Economy, Vol. 84, pp. 337-342.

Cairnes, J. E. (1874). Some Leading Principles of Political Economy. New York: Harper \& Brothers Publishers.

Chipman, John S. (1965).“A Survey of the Theory of International Trade: Part 1, The Classical Theory," Econometrica, Vol. 33, pp. 477-519.

Chipman, John S. (1971). “International Trade with Capital Mobility: A Substitution Theorem." In Trade, Balance of Payments, and Growth: Papers in Honor of Charles P. Kindleberger. Eds. J. Bhagwati, R. Jones, R. Mundell, and J. Vanek. Amersterdam: North-Holland.

Harrod, R. F. (1946). “John Maynard Keynes,” Review of Economics and Statistics, Vol. 28, pp. 178-182.

Harrod, R. F. (1951). The Life of John Maynard Keynes. London: Macmillan \& Co.

Hollander, Jacob H. (1911). "Ricardo and Torrens," Economic Journal, Vol. 21, pp. $455-$ 468.

Hollander, Samuel (1979). The Economics of David Ricardo. Toronto: The University of Toronto Press. 
Hollander, Samuel (1992). “Malthus's Abandonment of Agricultural Protectionism: A Discovery in the History of Economic Thought." American Economic Review, Vol. 82, pp. 650-659.

Irwin, Douglas (1996). Against the Tide: An Intellectual History of Free Trade. Princeton: Princeton University Press.

Jones , Ronald W (1967). "International Capital Movements and the Theory of Tariffs and Trade," Quarterly Journal of Economics, Vol. 81, pp. 1-38.

Jones, Ronald W. and Roy J. Ruffin (1975). “Trade Patterns with Capital Mobility," in M. Parkin and A. R. Nobay, eds. Current Economic Problems, Cambridge.

Kemp, Murray C. (1966).” The Gain from International Trade and Investment: A NeoHeckscher-Ohlin Approach," American Economic Review, Vol. 56, pp.788-809.

Kemp, Murray C. (1956). "Unilateral Transfers and the Terms of Trade American Economic Review, Vol. 46, pp. 106-127.

Keynes, J. M. (1924a). “Alfred Marshall, 1842-1924.” Economic Journal, Vol. 34, pp. $311-372$.

Keynes, J. M. (1924b). "Bibliographical List of the Writings of Alfred Marshall.” Economic Journal, Vol. 34, pp. 627-637.

Keynes, John M. (1956). Essays and Sketches in Biography. New York: Meridian Books.

Lang, Tim and Colin Hines (1993). The New Protectionism. New York: The New Press. Lerner, Abba P. (1936). “The Symmetry Betweem Import and Export Taxes.” Economica, Vol. 3, pp. 306-313. 
Maneschi, Andrea (1998). Comparative Advantage in International Trade: A Historical Perspective. Cheltenham: Edward Elgar

Maneschi, Andrea (2000). "Adam Smith, David Ricardo and the nature of advantage in trade." Southeastern Conference on Economic Theory and International Trade, September, 2000, Houston, Texas.

Mill, James. (1921). Elements of Political Economy. $1^{\text {st }}$. ed., London,; $3^{\text {rd }}$ ed., London: 1826, $4^{\text {th }}$ ed., London, 1844.

Mill, John Stuart (1844). Essay on some Unsettled Questions in Political Economy. London: John W. Parker.

Mill, John Stuart (1848). Principles of Political Economy, with some of the their Applications to Social Philosophy, London: Parker.

Ricardo, David (1951-1973), The Works and Correspondence of David Ricardo. Edited by Piero Sraffa and M. Dobbs. Vols. I-XI. Cambridge: Cambridge University Press.

Robbins, Lionel (1958). Robert Torrens and the Evolution of Classical Economics. London: Macmillan.

Rosen, Sherwin (1993). "George J. Stigler and the Industrial Organization of Economic Thought.” Journal of Political Economy. Vol. 101, pp. 809-817.

Rothbard, Murray N. (1995). Classical Economics. Cheltenham: Edward Elgar Publishing Limited.

Ruffin, Roy J.(1988). "The Missing Link: The Ricardian Approach to the Factor Endowment Theory of International Trade.' American Economic Review Vol. 78, pp. 759-772. 
Ruffin, Roy J. (1984). “International Factor Movements.” In R. W. Jones and P.B. Kenen, Handbook of International Economics, Vol. I. Amsterdam: NorthHolland, pp. 237-288.

Samuelson, Paul A. (1953). "Prices of Factors and Goods in General Equilibrium," Review of Economic Studies, Vol. 21, pp. 1-20.

Samuelson, Paul A. (1962). "Economists and the History of Ideas," American Economic Review, Vol. 52, pp. 1-18.

Samuelson, Paul A. (1972), "The Way of an Economist." Reprinted in The Collected Papers of Paul A. Samuelson. Ed. R. C. Merton. Cambridge: Cambridge MIT Press.

Sayers, R. S. (1953). “Ricardo's Views on Monetary Questions,"'Quarterly Journal of Economics, . Vol. 67, pp. 30-49.

Schumpeter, Joseph (1954). History of Economic Analysis. Great Britain: Allen \& Unwin.

Seligman, Edwin R. A., “On Some Neglected British Economists,” Economic Journal, Vol. 13, No. 51. (Sep., 1903), pp. 335-363.

Seligman, Edwin R. A. (1911). "Ricardo and Torrens," Economic Journal, Vol. 21,, pp. $448-455$.

Sraffa, Piero (1930). “An Alleged Correction of Ricardo,” Quarterly Journal of Economics, Vol. 44, pp. 539-545.

Stigler, George J (1958).“Ricardo and the 93\% Labor Theory of Value.”American Economic Review, Vol. 48, pp. 357-367.

Torrens, Robert. Essay on the External Corn Trade. London: J. Hatchard, 1815. 
Torrens, Robert (1844). The Budget: On Commercial and Colonial Policy. London: Smith, Elder, and Co.

Thweatt, William O. (1976). "James Mill and the Early Development of Comparative Advantage.” History of Political Economy, Vol. 8, pp. 207-234.

Thweatt, William O. (1987). “James and John Mill on Comparative Advantage: Sraffa's Account Corrected.” Edited by H. Visser and E. Schoorl, Trade in Transit, Dordrecht: Kluwer Academic Publishers.

Viner, Jacob (1937). Studies in the Theory of International Trade. New York: Harper \& Brothers.

Williams, John H. (1929). “The Theory of International Trade Reconsidered.” Economic Journal, Vol. 39, pp. 195-209. 